\title{
IbM Pelatihan Formulasi Sabun Padat Susu Kambing
}

\section{Science for the Community: Training on Goat Milk Solid Soap Formulation}

Uswatun Chasanah*
Dyah Rahmasari
Mutiara Titani
Universitas Muhammadiyah Malang,
Malang, East Java, Indonesia
*email: uswatun@umm.ac.id
Kata Kunci
Formulasi
Sabun Padat
Susu Kambing Segar
Keywords:
Formulation
Solid Soap
Fresh Goat Milk
Received: October 2019
Accepted: December 2019
Published: March 2020

\begin{abstract}
Abstrak
Telah dilaksanakan pelatihan tentang formulasi sabun padat susu kambing kepada masyarakat. Mitra dari kegiatan ini adalah sekelompok masyarakat penghasil susu kambing segar ettawa yang bertempat tinggal di desa Torongrejo, Klerek, kota Batu. Proses pelatihan formulasi sabun padat susu kambing diawali dengan ceramah tentang formulasi sabun padat, kemudian dilanjutkan workshop pembuatan sabun padat susu kambing. Capaian dari kegiatan ini adalah adanya peningkatan pengetahuan sekaligus ketrampilan pihak Mitra tentang formulasi dan pembuatan sabun padat susu kambing.
\end{abstract}

\begin{abstract}
Training has been held on the formulation of goat milk solid soap to the community. The partners of this activity are a group of fresh Ettawa goat milk producing communities who live in the village of Torongrejo, Klerek, Batu city. The training process for goat milk solid soap formulation begins with a lecture on solid soap formulation, then proceed with a workshop on making goat milk solid soap. The achievement of this activity is an increase in knowledge as well as the skills of the Partners regarding the formulation and manufacture of goat milk solid soap.
\end{abstract}

(c) 2020 Uswatun Chasanah, Dyah Rahmasari, Mutiara Titani. Published by Institute for Research and Community Services Universitas Muhammadiyah Palangkaraya. This is Open Access article under the CC-BY-SA License (http://creativecommons.org/licenses/by-sa/4.0/). DOI: https://doi.org/10.33084/pengabdianmu.v5i2.1035

\section{PENDAHULUAN}

Kota Batu yang terletak 800 meter di atas permukaan air laut dikaruniai keindahan alam yang memikat, dengan kondisi topografi pegunungan dan perbukitannya, menjadikan kota Batu terkenal sebagai daerah dingin. Kondisi suhu minimum $18-24^{\circ} \mathrm{C}$ dan suhu maksimum $28-32^{\circ} \mathrm{C}$, kelembaban udara sekitar $75-98 \%$, dan curah hujan rata-rata 875-3000 mm per tahun menjadikan Kota Batu sangat cocok untuk pengembangan tanaman holtikultura dan peternakan (Aridiansari et al., 2015). Di Kota Batu terdapat beberapa sentra usaha peternakan, salah satu diantaranya adalah peternak Kambing Ettawa yang berlokasi di desa Torongrejo kecamatan Junrejo, yang dalam hal ini adalah sebagai Mitra Program Pengabdian kepada Masyarakat (Sujono et al., 2019a). Produk susu kambing ettawa yang dihasilkan dari lokasi tersebut digunakan dalam Pengembangan berbagai produk Makanan maupun Kesehatan, seperti yoghurt maupun sebagai bahan baku sabun padat (Sujono et al., 2019b; Akhiriani \& Indrayani, 2017).

Sebagaimana telah diketahui bahwa susu kambing kaya akan lemak, protein, mineral dan vitamin yang sangat bermanfaat untuk kesehatan kulit (Khan et al., 2019; Getaneh et al., 2016). Kandungan zat asam beta hidroksil alami dalam susu kambing mampu mencerahkan kulit sehingga kulit menjadi lebih halus dan tidak bersisik (Tran et al., 2015). Kandungan protein dalam susu 
kambing berfungsi sebagai pemberi nutrisi yang berfungsi melembabkan sekaligus melapisi permukaan kulit sehingga menjadi lebih halus dan kenyal (Purwati et al., 2012).

Hingga saat ini, usaha Mitra selain produksi susu kambing ettawa segar, juga telah menghasilkan produk varian susu kambing ettawa yang berupa yogurt dan kefir. Menyadari banyak sekali manfaat susu kambing untuk kesehatan kulit maka Mitra tertarik untuk pula untuk mendapatkan pelatihan tentang cara pembuatan sabun padat berbahan dasar susu kambing segar. Pihak mitra berharap dengan adanya tambahan ketrampilan tentang pengolahan susu kambing segar menjadi sabun padat, maka akan ada peluang untuk menambah varian produk berbahan susu kambing segar. Merespon keinginan tersebut maka dilakukan kegiatan pengabdian masyarakat dengan tema "Pelatihan Formulasi dan Praktek Pembuatan Sabun Padat Susu Kambing Segar"oleh Tim dari Program Studi Farmasi Fakultas IlmuKesehatan Unversitas Muhamamdiyah Malang.

\section{METODOLOGI}

Metode pelaksanaan program pengabdian masyarakat ini adalah dalam bentuk kegiatan workshop. Sebelum kegiatan workshop dilaksanakan, maka telah dipersiapkan bahan dan alat yang dibutuhkan untuk membuat sabun padat. Bahan untuk membuat sabun padat adalah minyak kelapa sawit, minyak kelapa, minyak zaitun, minyak jarak, pewarna, minyak fragrance, Natrium Hidroksida $(\mathrm{NaOH})$, Titanium dioksida (TiO2), dan susu kambing segar. Sedangkan peralatan yang diperlukan untuk membuat sabun padat susu kambing adalah hand blender mixer, silicon pencetak sabun, pemotong sabun, timbangan digital, gelas atau plastik ukur, baskom, dan spatel.
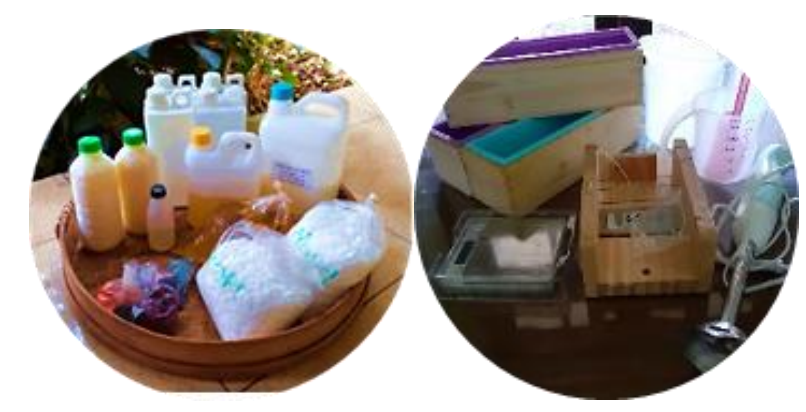

Gambar 1. Bahan (kiri) dan alat (kanan) untuk pembuatan sabun padat susu kambing.

Pelaksanaan workshop diadakan di tempat tinggal Mitra. Kegiatan ini diawali dengan penyampaian materi tentang pembuatan sabun padat berbahan susu kambing segar. Sebagai sumber materi pelatihan mengacu pada materi yang tersedia pada http://www.northcountrymercantile.com/soapmakin glibrary/lye-calculator/ dan http://soapcalc.net/. Materi yang disampaikan antara lain tentang prinsip reaksi penyabunan/saponifikasi, sifat berbagai jenis minyak, cara perhitungan kebutuhan soda $(\mathrm{NaOH})$, dan yang paling penting adalah teknis pencampuran jika digunakan bahan susu kambing segar.

Setelah penyampaian materi selesai dilanjutkan dengan praktik pembuatan sabun padat berbahan dasar susu kambing dengan cara dingin (cold process). Peserta workshop dibagi menjadi tiga kelompok dan masingmasing dipandu oleh seorang mahasiswa yang terlibat pada kegiatan program pengabdian ini. Tentang proses pembuatannya lebih detail dapat dilihat secara daring melalui tautan yang tersedia pada blog https://uswatunchasanah1.blogspot.com.

\section{HASIL DAN PEMBAHASAN}

Kegiatan pelatihan pembuatan sabun padat susu kambing diikuti oleh tujuh orang penghasil susu kambing segar ettawa yang bertempat tinggal di desa Torongrejo, Klerek, kota Batu, Jawa Timur. 
Pada sesi pertama saat disampaikan materi tentang formulasi sabun padat berbahan susu kambing segar banyak sekali pertanyaan yang dilontarkan oleh peserta baik tentang formulasi maupun kemudahan untuk memperoleh bahan baku.

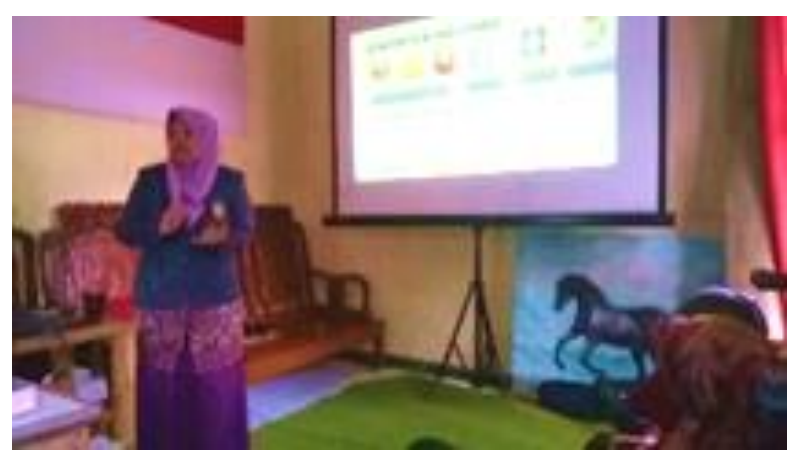

Gambar 2. Penyampaian materi pembuatan sabun padat susu kambing.

Formula sabun yang dipraktikkan oleh masing-masing kelompok sengaja dibuat berbeda sehingga mereka secara langsung dapat mencermati sifat dari minyakminyak yang dipilih pada setiap formulasi. Tergantung dari jenis minyak yang digunakan akan berakibat langsung pada cepat dan lamanya proses pembuatan sabun dan sifat sabun yang dihasilkan. Misalnya jika dikehendaki agar proses pembuatan sabun menjadi lebih singkat, maka dalam formulasi harus terdapat minyak jarak dan sedikit mengandung minyak zaitun (Widyasanti \& Rohani, 2017). Selain itu mereka menjadi terampil untuk memilih jenis minyak yang digunakan disesuaikan dengan sifat sabun yang diinginkan yang meliputi tingkat kekerasan sabun, daya membersihkan, banyaknya busa yang terbentuk, kelembutan busa yang dihasilkan, juga efek melembabkan pada kulit.

Ketrampilan untuk memanfaatkan "lye calculator" sangat membantu untuk mengetahui jumlah soda $(\mathrm{NaOH})$ pada formula yang dipilih, sehingga resiko efek iritasi akibat penggunaan sabun yang salah formula bisa dihindari dan sabun yang dihasilkan memenuhi standar SNI 3532:2016 tentang sabun mandi padat (Standar Nasional Indonesia, 2016). Sebelumnya mereka selalu gagal untuk membuat sabun padat yang mengandung susu kambing segar, namun setelah mengikuti pelatihan ini mereka menjadi paham tahapan paling kritis pada proses pembuatan sabun padat susu kambing. Mereka menjadi tahu pentingnya membuat sabun padat yang mengandung susu kambing segar harus dengan metode dingin, karena reaksi antara susu kambing segar dan $\mathrm{NaOH}$ adalah menghasilkan panas yang dapat mengakibatkan susu menjadi pecah atau langsung menjadi coklat, jika suhu terlalu tinggi akan mengakibatkan susu kambing seketika menjadi pecah (Retnowati et al., 2013).

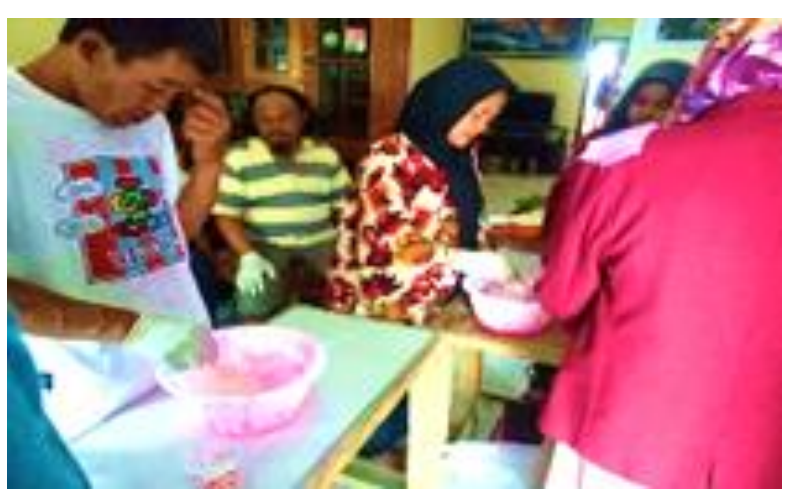

Gambar 3. Praktek pembuatan sabun padat susu kambing.

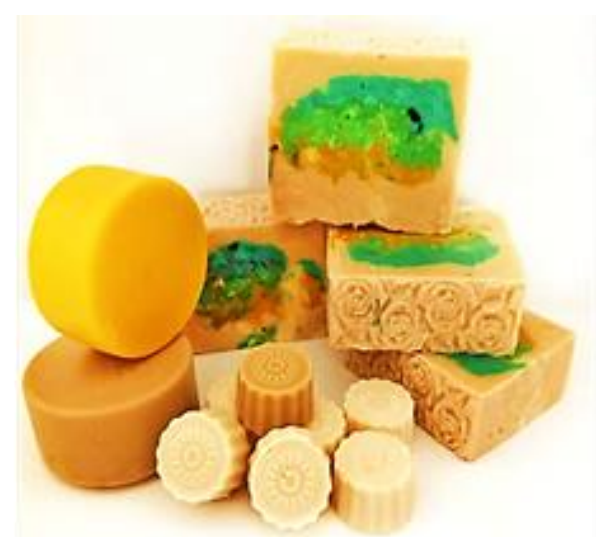

Gambar 4. Sabun padat susu kambing yang dihasilkan dari kegiatan pengabdian.

Selesai pelatihan, kepada pihak Mitra diberikan hibah berupa peralatan sederhana yang antara lain adalah alat pencetak sabun, alat pemotong sabun, hand blender mixer, dan timbangan digital. Selain itu juga diberikan 
pula bahan baku untuk keperluan pembuatan sabun padat dengan jumlah yang memadai. Dengan bantuan alat dan bahan ini pihak mitra dapat langsung praktik mandiri untuk membuat sabun padat yang mengandung susu kambing segar.

\section{KESIMPULAN}

Secara singkat hasil dari kegiatan ini bagi pihak Mitra adalah berupa peningkatan pengetahuan dan ketrampilan formulasi sabun padat susu kambing. Mereka trampil merancang formula sabun dengan bahan dasar berbagai jenis minyak yang dikombinasikan dengan susu kambing segar. Menanggapi permintaan dari pihak Mitra sebagai tindak lanjut dari kegiatan ini adalah akan diselenggarakan pelatihan untuk pembuatan sabun cair dengan bahan susu kambing segar.

\section{UCAPAN TERIMA KASIH}

Terimakasih kepada Universitas Muhammadiyah Malang yang telah memberikan bantuan pendanaan melalui Direktorat Penelitian dan Pengabdian Masyarakat Unversitas Muhamamdiyah Malang Tahun Anggaran 2018/2019, mahasiswa yang telah membantu kegiatan ini, juga pihak Mitra yang telah memfasilitasi tempat sehingga kegiatan pelatihan dapat berlangsung dengan baik.

\section{REFERENSI}

Akhiriani, S., Indrayani, N.M. 2017. Peningkatan Produktivitas Agroindustri Sabun Susu Kambing Etawa "AFINDA". Warta Pengabdian. 11(4):121-138.

Aridiansari, R., Nurlaelih, E.E., Wicaksono, K.P. 2015. Pengembangan Agrowisata Di Desa Wisata Tulungrejo Kota Batu, Jawa Timur. Jurnal Produksi Tanaman.3(5):383-390.
Getaneh, G., Mebrat, A., Wubie, A., Kendie, H. 2016. Review on Goat Milk Composition and its Nutritive Value. Journal of Nutrition and Health Sciences. 3(4):1-10. https://doi.org/10.15744/2393-9060.3.401

Khan, I.T., Bule, M., Ullah, R., Nadeem, M., Asif, S., Niaz, K. 2019. The antioxidant components of milk and their role in processing, ripening, and storage: Functional food. Veterinary World. 12(1):12-33.

https://dx.doi.org/10.14202/vetworld.2019.1 2-33

Purwati, E., Vebriyanti, E., Suharto, E.L.S. 2012. Sabun Susu Kambing Virgin Coconut Oil Dapat Meningkatkan Kesehatan Kulit Melalui $\mathrm{pH}$ dan Bakteri Baik (Bakteri Asam Laktat) serta Meningkatkan Pendapatan Masyarakat. In Prosiding Seminas Competitive Advantage II. Jombang: Universitas Pesantren Tinggi Darul 'Ulum.

Retnowati, D.S., Kumoro, A.C., Ratnawati, Budiyati, C.S. 2013. Pembuatan dan Karakterisasi Sabun Susu dengan Proses Dingin. Jurnal Rekayasa Proses. 7(2):46-51. https://doi.org/10.22146/jrekpros.4951

Standar Nasional Indonesia. 2016. SNI 3532:2016. Sabun mandi padat.

Sujono, S., Khotimah, K., Kusuma, H. 2019a. Usaha PPUPIK Pembibitan Kambing Perah Unggul dan Olahan Produk Susu Kambing. Jurnal Solma. $\quad$ 8(2):330-338. https://doi.org/10.29405/solma.v8i2.3530

Sujono, S., Rofat, M.R.A., Kusuma, H., Khotimah, K. 2019b. Tekstur Yoghurt Susu Kambing dengan Perbedaan Jenis Starter dan Lama Fermentasi. PengabdianMu: Jurnal Ilmiah Pengabdian Kepada Masyarakat. 4(2):55-60. https://doi.org/10.33084/pengabdianmu.v4i 2.687

Tran, D., Townley, J.P., Barnes, T.M., Greive, K.A. 2015. An antiaging skin care system containing alpha hydroxy acids and vitamins improves the biomechanical parameters of facial skin. Clinical, Cosmetic and Investigational Dermatology. 8:9-17. https://dx.doi.org/10.2147/CCID.S75439 
Widyasanti, A., Rohani, J.M. 2017. The making of transparent soap based on olive oil with the addition of white tea extract. Jurnal Penelitian Teh dan Kina. 20(1):13-29. https://doi.org/10.22302/pptk.jur.jptk.v20i1. 124 